\title{
SELF-EDUCATION AS A MEANS OF LEADERSHIP QUALITIES FORMATION IN FUTURE OFFICERS-COMMANDERS OF THE NATIONAL GUARD OF UKRAINE
}

\author{
Bohdan Lutsenko \\ Postgraduate Student, National Technical University "Kharkiv Polytechnic Institute", Ukraine \\ e-mail: bohdan3888@ukr.net,orcid.org/0000-0003-2302-0058
}

\section{Summary}

The problem of leadership, formation and development of leadership qualities has long been the focus of the scientific community. But it has become especially important in recent decades. And this is no accident. The global changes taking place in the world have significantly increased the demand for leaders - people who are able to unite, lead and successfully solve the tasks.

This fully applies to officers-commanders of the National Guard of Ukraine. In modern conditions, there is a clear need for the formation of leadership qualities in future graduates of military educational institutions, on whose shoulders immediately after graduation lies a great responsibility for the management of units.

At the same time, the analysis of responses of the military leadership of the state shows that a significant number of young officers do not have established leadership qualities. Many of them get lost in difficult situations. They lack the ability to quickly adapt to the new environment, responsibility, independence, initiative, physical endurance, flexibility in establishing relationships with subordinates, professional skills, competencies and organizational skills that underlie the authority of the commander.

The result is a situation where there are a large number of managers, but there is a lack of leaders. This is especially detrimental in changing situations of service and combat activities, where the only chance for success is often a manifestation of the commander's leadership qualities.

During training, it is still difficult for a future officer to understand which of his qualities will be decisive and which should be developed. Therefore, during training it is advisable to form a stable motivation for continuous self-development, which will allow you to constantly grow professionally and personally.

The purpose of the article is to theoretically substantiate the process of self-education as a means of forming leadership qualities of a young officer.

Keywords: motivation, self-education, self-upbringing, self-obligation, selforganization, self-training, self-control.

\section{DOI https://doi.org/10.23856/3924}

\section{Introduction}

The realities of today require a new look at the process of training future servicemen of the National Guard of Ukraine, their capabilities and abilities, including in terms of personal development. Education traditionally includes learning, upbringing and personal development. Accordingly, self-education consists of self-learning, self-upbringing and self-development. The formation of leadership qualities of the officer-commander will be successful if the cadets want to develop their own personality, is the need for self-education. With an active and purposeful approach to self-education, the individual is able to achieve significant development of 
the qualities he needs. This determines the significant role of self-education in the formation of leadership qualities of the future officer-commander of the National Guard of Ukraine.

\section{Literature reviews and theoretical framework}

Analysis of the scientific literature proves that the concept of "self-education" has been thoroughly studied by various branches of science, so L. Vishnevskaya (Vishnevskaya, 2009), based on psychological and pedagogical research, notes that the definition of "self-education" consists of the following elements: cognitive essence; close connection with self-upbringing of the individual; personal development based on systematic and purposeful activities related to social conditions.

The pedagogical dictionary defines self-education (Bim-Bad, 2003: 252) as purposeful cognitive activity, which is managed by the individual; acquisition of systematic knowledge in any field. At the heart of self-education is a harmonious combination of interest in learning and independent study of the material.

Psychological Dictionary (Mesheryakov, 2004: 429) gives the following interpretation: self-education - education that is obtained independently, outside the walls of any educational institution, without the help of the educational process; informal individual form of educational activity.

That is, self-education is self-organized by the subject of learning that meets his needs for knowledge and personal growth.

According to N. Bankovskaya (Bankovskaya, 2010), self-learning is defined as a process of independent education without the direct participation of the teacher, and self-education as a way to acquire knowledge, skills, skills on the initiative of the student on the subject of knowledge, scope and source of knowledge, as well as the choice of forms of satisfaction of cognitive interests and needs.

The main condition for the intensification of independent activity, continuity and efficiency of the process of self-education is a person's motivation - the formation of the necessary leadership qualities for the future officer in order to successfully perform the tasks set before him.

Realizing the need to form the qualities of a leader and assessing their own preparedness in this aspect (stage of motivation), the cadet aims to achieve the desired ideal. It analyzes its capabilities, the external environment, and predicts possible options for achieving the goal. Then the future officer makes a decision and only then proceeds to the planning stage. The planning stage involves drawing up a personal self-education plan. In our opinion, the self-education plan should contain the following points:

- goals of self-education;

- tasks of self-education;

- thematic blocks of self-education;

- terms of work on thematic blocks of self-education;

- main issues of thematic blocks of self-education;

- forms, methods and means of self-education;

- expected result;

- assessment of the actual result;

- reflection.

Means of self-education of cadets can be: educational, scientific, fiction, monographs, memoirs, attending trainings, audio and video materials, Internet resources, social media. The main form of self-education is the study of literature and other sources, methods of self-education are independent work on information sources, independent exercises and practical tasks, communication with teachers, staff, senior commanders. The cadet must master the methods and 
techniques of working with different sources of information, which will quickly find the necessary information from different sources, analyze, synthesize, use the information in practice.

According to E. Gluhova (Gluhova, 2010) and A. Lopuha (Lopuha, Strabykin, 2015) the educational environment of a military educational institution should be aimed at the development of motivational and goal-setting components of cognitive activity, as well as learning ways of independent cognition, the formation of skills to solve creative problems. Under such conditions, the future officer develops the ability to set goals, the dominance of active cognitive interest, which will achieve a high level of self-education and form leadership qualities.

Given the above, the process of self-education of the cadet should be divided into the following stages:

1) recognition of the need and formulation of the purpose of self-education;

2) action plan to achieve the goal of self-education;

3) assessment of achievements and making adjustments (if necessary).

Thus, self-education is one of the components of the formation of leadership qualities of the future officer-commander of the National Guard of Ukraine. In addition, self-education, as part of the process of forming leadership qualities of the cadet, determines and is closely related to self-upbringing.

\section{The connection between self-education and self-upbringing}

Researcher A. Manukyan (Manukyan, 2007) understands the self-upbringing of servicemen as organized, active, purposeful activity on the systematic formation and development of positive and elimination of negative personality traits in accordance with the requirements of military service.

Self-upbringing is preceded by an analysis of their own abilities and capabilities. Effective self-upbringing is possible under the condition of adequate self-assessment, which corresponds to the real capabilities of the cadet. A number of factors and conditions contribute to the formation of leadership qualities of the officer-commander of the National Guard of Ukraine through self-upbringing, namely:

factors:

- self-upbringing determines the development of professional self-awareness of the officer;

- self-upbringing is due to a set of stable motives, characterized by values, interests that correspond to the personality of the officer;

- self-upbringing of the individual is an indicator of the desire of the future officer to self-realization and development of the necessary qualities, as well as the formation of professional competencies;

- mastering the techniques and methods of self-upbringing contributes to an adequate assessment of their capabilities and difficulties that stand in the way of achieving this goal.

conditions:

- actualization of the need for self-upbringing;

- development of the ability to self-knowledge of one's own personality in the professional field and interpersonal interaction;

- learning approaches to setting goals for self-upbringing, program design, choice of methods and means of self-upbringing.

At the initial stage of the process of self-upbringing, the future officer-commander needs to determine his abilities and capabilities for the formation of leadership qualities, as well as the existing level of development of the necessary qualities. That is, there is a stage of self-knowledge. 
Self-knowledge is carried out in three areas:

1) self-awareness in the role of officer-commander of the National Guard of Ukraine; awareness of the system of requirements for a military service officer, to form an idea of the prospects of military service;

2) determining the existing qualities of a leader through self-observation and self-analysis;

3 ) assessment of readiness for the development of the necessary qualities of a leader in order to create their own project of self-organization of activities for the development of leadership qualities.

Necessary conditions for objective self-assessment are a critical attitude to oneself, the ability to adequately respond to the comments of colleagues, senior commanders and superiors.

Based on self-knowledge, the future officer-commander decides on the need for self-upbringing and moves to the stage of planning self-upbringing, is creating a model of work on yourself.

Self-education planning includes a number of interrelated tasks, namely: finding out the purpose and basic principles of self-education. The content of self-education and ideals to which it is necessary to aspire are defined. At the same time, the ideal should not be a generalized type of personality and qualities, but specific officers of the past and present, who have demonstrated the real presence of leadership qualities.

On the basis of the defined purposes and tasks the program of self-upbringing which develops on a certain life stage and further (if necessary) is specified and corrected is developed. The self-education program is individual and designed to organize work on yourself and should contain the following components:

- areas of work on the formation of leadership qualities;

- means and methods of implementation of certain work;

- deadlines for tasks.

Preparatory work carried out at the stage of self-knowledge and planning, creates the necessary basis for successful work in the subsequent stages of self-education.

The system of work on development of positive qualities of the person and elimination of negative, connected with an effective technique of self-education acts as practical actions concerning realization of the program of self-upbringing.

Under the methods of self-upbringing A. Manukyan (Manukyan, 2007) understands a set of techniques of homogeneous pedagogical influence of man on himself in order to develop the necessary personal qualities, and considers the techniques as a private influence of man on himself, which represents in each case a single act.

Despite the individuality of the system of methods and techniques of self-upbringing, we can distinguish general methods:

self-belief - the future officer recognizes the need to form the qualities of a leader and eliminate the shortcomings that arise at this stage. There is a kind of resolution of contradictions between personal views, opinions, feelings and demands of the service, opinions and views of an authoritative person, team, public opinion. Thoughts and views determined by self-belief give the cadet confidence, moral and psychological stability.

self-obligation - is the desire of the future officer to engage in self-upbringing in the chosen direction, thereby forming an inner readiness for active and purposeful work. The mechanism of implementation of this method is that, taking on the obligation to engage in self-upbringing, cadets, thereby, mobilize their forces, develop an inner readiness for active and purposeful work on themselves;

self-organization - is to organize their behavior and activities in accordance with the rules of conduct, provided the ability to manage themselves, to achieve their goals. The cadet's ability to manage himself, to achieve goals is an important condition for self-organization; 
autotraining - a method based on emotional and volitional training, the meaning of which is to develop the ability to influence psychoregulators processes. To do this, with the help of self-suggestion of special verbal formulas, a person introduces into long-term memory (at the subconscious level) a certain model of ideas, which further affects human behavior. The tools of purposeful self-influence are special exercises of self-suggestion in the form of verbal formulas. In the process of such training, the future officer is able to create a model of ideas, feelings, emotions, states, introduce it into his psyche by focusing or repeating it many times;

self-control - summarizing the results of self-upbringing. Its essence is that the cadets, analyzing the process of self-education, identify deviations of the implemented program of self-education from the planned and make appropriate adjustments to the plan of work on themselves.

The implementation of methods of self-education is carried out through the use of pedagogically homogeneous techniques: self-suggestion, self-criticism, self-promotion, self-coercion, self-reminiscence, self-report.

All stages of the process of self-upbringing undergo a stage of self-control and self-correction (if necessary).

Self-control - the most important activity of the individual, aimed at self-management and self-improvement of their work. It organically includes analysis, evaluation and self-monitoring of the course and results of self-upbringing, correction and elimination of shortcomings in the planning and organization of the process of self-education. The main condition for the effectiveness of the method of self-control is an objective and comprehensive self-demand.

In order to self-control the future officer must keep a diary of self-education, the value of which is to record life events and analysis of activities, motives for actions to determine their importance in the formation of leadership qualities.

Thus, the analysis of the process of self-upbringing gives grounds to draw a conclusion about the complexity and versatility of the individual's work on himself in order to form the leadership qualities of the officer-commander of the National Guard of Ukraine. The effectiveness of this work is to master the principles of self-upbringing planning, methods and techniques of self-upbringing and self-control.

\section{Conclusion}

As a result, we note that self-education is a complex and multifaceted pedagogical process with its inherent internal contradictions. Experiencing significant difficulties in self-education at different stages, without mastering an effective method of self-education, you can lose motivation for self-education. Therefore, the process of self-education of future officers should be periodically monitored. Self-education must be constantly managed by providing pedagogical guidance. At the same time, self-education is a means of self-upbringing, as it contributes to the development of purposefulness, persistence in achieving goals, internal organization and diligence. The content, organization and methods of self-education of the future officer-commander for training in a military educational institution is determined by the ability to work with various sources of information. The greatest effectiveness of self-education is achieved when the cadet deeply and self-critically assesses the initial level of their knowledge, skills and abilities, clearly defines the program of their improvement, takes into account the assessment of their activities by management and cadet staff. The solution of this problem is greatly facilitated by the introduction into the daily practice of self-upbringing and self-education of future officers-commanders of the scientific bases developed by pedagogical science. The cadet must independently be active in improving their personality, strive to become a competent professional. 


\section{References}

Bankovskaya, N. (2010). Issledovanie motivacionnyh harakteristik samoobrazovaniya studentov [Research of motivational characteristics of self-education of students]. Izvestiya TulGU. Gumanitarnye nauki, 2, 282-294. [in Russian].

Bim-Bad, B. (2003). Pedagogicheskij enciklopedicheskij slovar [Pedagogical encyclopedic dictionary]. Moskva: Bolshaya Rossijskaya enciklopediya. [in Russian].

Gluhova, E. (2010). Mezhpredmetnye svyazi kak sredstvo samoobrazovaniya studentov $v$ vuze [Interdisciplinary connections as a means of self-education of students at a university]. Chelyabinsk. [in Russian].

Lopuha, A., Strabykin, A. (2015). Camoobrazovanie kursantov voennogo vuza v sovremennyh usloviyah [Self-education of cadets of a military university in modern conditions]. Mir nauki, kultury, obrazovaniya, 6 (55), 209-212. [in Russian].

Manukyan, A. (2007). Samovospitanie voennosluzhashih kak faktor samosovershenstvovaniya lichnosti budushih oficerov [Self-education of servicemen as a factor in the self-improvement of the personality of future officers]. Izvestiya Rossijskogo gosudarstvennogo pedagogicheskogo universiteta im. A. I. Gercena, 18, 44, 390-395. [in Russian].

Mesheryakov, B. (2004). Bolshoj psihologicheskij slovar [Big psychological dictionary]. SanktPeterburg: Pajm-Evroznak. [in Russian].

Vishnevskaya, L. (2009). Samoobrazovanie kak psihologo-pedagogicheskaya problema [Selfeducation as a psychological and pedagogical problem]. Izvestiya PGPU im. V. G. Belinskogo, 12 (16), 156-158. [in Russian]. 